University of Nebraska - Lincoln

DigitalCommons@University of Nebraska - Lincoln

USDA National Wildlife Research Center - Staff Publications
U.S. Department of Agriculture: Animal and Plant Health Inspection Service

January 1980

\title{
COMPENSATORY RESPONSE OF MATURING CORN KERNELS FOLLOWING SIMULATED DAMAGE BY BIRDS
}

\author{
Paul P. WORONECKI \\ U.S. Fish \& Wildlife Service, Denver Wildlife Research Center, Ohio Field Station \\ Robert A. Stehn \\ U.S. Fish \& Wildlife Service, Denver Wildlife Research Center, Ohio Field Station \\ Richard A. Dolbeer \\ U.S. Fish \& Wildlife Service, Denver Wildlife Research Center, Ohio Field Station
}

Follow this and additional works at: https://digitalcommons.unl.edu/icwdm_usdanwrc

Part of the Environmental Sciences Commons

WORONECKI, Paul P.; Stehn, Robert A.; and Dolbeer, Richard A., "COMPENSATORY RESPONSE OF MATURING CORN KERNELS FOLLOWING SIMULATED DAMAGE BY BIRDS" (1980). USDA National Wildlife Research Center - Staff Publications. 144.

https://digitalcommons.unl.edu/icwdm_usdanwrc/144

This Article is brought to you for free and open access by the U.S. Department of Agriculture: Animal and Plant Health Inspection Service at DigitalCommons@University of Nebraska - Lincoln. It has been accepted for inclusion in USDA National Wildlife Research Center - Staff Publications by an authorized administrator of DigitalCommons@University of Nebraska - Lincoln. 


\title{
COMPENSATORY RESPONSE OF MATURING CORN KERNELS FOLLOWING SIMULATED DAMAGE BY BIRDS
}

\author{
BY PAUL P. WORONECKI, ROBERT A. STEHN AND \\ RICHARD A. DOLBEER \\ U.S. Fish \& Wildlife Service, Denver Wildlife Research Center, \\ Ohio Field Station, Sandusky 44870, U.S.A.
}

\begin{abstract}
SUMMARY
(1) A study was made to measure compensatory growth responses and to estimate losses associated with bird damage to maturing corn.

(2) Corn kernels contain $20-40 \%$ of their final biomass at the time they are usually consumed by blackbirds.

(3) Very slight compensation of kernel weight occurred following simulated bird damage to tip kernels.

(4) Heavy bird damage, early in kernel development, increased fungal, sprouting, and insect damage before harvest.

(5) Estimates of bird damage, subsequent secondary damage, and compensation were affected by the amount of damage, maturity of the kernels at the time of damage, and environmental factors before, during, and after damage.

(6) Visual estimates of weight change were closely correlated with actual loss of the total kernel weight.

(7) Studies of food habits and bioenergetics that have used feeding rates and numbers of birds to estimate the impact of blackbirds on corn crops may have underestimated reductions in corn yields.
\end{abstract}

\section{INTRODUCTION}

Red-winged blackbird (Agelaius phoeniceus) damage to maturing corn (Zea mays) in the milk and dough stages has often been considered a severe problem in localized areas of the United States (Stone et al. 1972). Most estimates of primary loss to corn yields have been based on visual or measured surface area estimates of damage to individual ears (Linehan 1967; De Grazio et al. 1969; DeHaven 1974; Granett et al. 1974). These methods of estimation of loss ignore any compensatory growth in the undamaged kernels and any secondary losses from insects and disease that may occur following damage.

Numerous studies of fruit, small grain, and hay have shown that moderate injury or loss to stems, leaves, roots, or fruit can occur before yield is actually affected (Stern 1973; Harriss 1974; Smith \& Kendall 1975; Webster \& Walker 1977; Dyer \& Bokhari 1976; Allen 1977; Summers \& Pollock 1978; Free \& Williams 1978; Wolff 1978). Compensation in maturing corn has been suggested by Linehan (1967), Dawson (1970), Dyer (1975, 1976) and Woronecki, Ingram \& Dolbeer (1976). However, studies by Duncan \& Hatfield (1964), although not addressing the question of compensation following bird damage per se, indicated that removal of non-apical kernels during development had no effect on the growth of the remaining kernels. 
Our previous study (Woronecki, Ingram \& Dolbeer 1976) suggested that net loss of shelled corn weight was a function of both the level of damage and the maturity of the ear at the time of damage. It also showed that low levels of bird damage could be partially compensated by increased kernel weight. Regardless of maturity, damage of less than six kernels per ear resulted in no net loss and in some instances in increased yield. The conclusions from that experiment are now reconsidered because primary and secondary damage had not been adequately quantified. Modifications were made in the present experiment to eliminate some of the disparities contributing to weight loss of shelled corn and to reduce sampling errors so both compensatory growth responses and secondary losses associated with bird damage to maturing corn could be accurately measured.

\section{METHODS}

\section{Experimental design and simulated bird damage}

The experiment was conducted in Huron County, Ohio, in a 0.2 ha plot within a 32.4 ha field planted on 1 May 1977 with Pioneer 3518 (120 day) field corn. The plot, $60 \mathrm{~m}$ from any field edge, contained plants of uniform height and maturity. At the time of silking (when cobs, husk, and shank are nearly developed), the plot was gridded into eighty subplots (six rows by $5 \mathrm{~m}$ ). Subplots with voids, gaps, or fewer than seventy plants with silking ears of corn were not included in the test.

The plot, in addition to normal commercial agricultural practices, was aerially treated with carbaryl insecticide (Sevin) 7 and 14 days after silking to reduce insect damage. A propane exploder and shotgun patrol were maintained in the field to ensure that damage by real birds was minimized.

Experimental units (fifty-six subplots and ten alternates) were randomly selected from all acceptable subplots. At the blister stage of ear growth (76 days after emergence), the first seventy top ears within each experimental unit (including alternates) that met the following criteria were tagged: at least $11 \mathrm{~cm}$ in length from the base of the corn ear to tip of ear; not irregular in shape or improperly developed or pollinated; and not showing any signs of tip emergence, fungus, insect, or bird damage. Within each experimental unit, thirty of the tagged ears were randomly selected to be artificially damaged and another thirty tagged ears were controls. The ten alternate ears remained to be used if any of the sixty selected ears were unacceptable at the time damage was to be inflicted.

We used two stages of corn maturity and seven levels of simulated bird damage to form a total of fourteen treatments (Table 1). The two maturity stages were: milk (22 days after silking) and dough ( 7 days after milk). These stages of corn maturity encompass the

TABLE 1. Description of the seven levels of simulated damage

$\begin{array}{cccc}\text { Damage level } & \begin{array}{c}\text { Number of apical } \\ \text { kernels damaged }\end{array} & \begin{array}{c}c a \% \\ \text { of total kernels } \\ \text { that were damaged* }\end{array} & \begin{array}{c}\text { Pattern of damage } \\ \text { (kernels across } \\ \times \text { kernels down) }\end{array} \\ 1 & 0 \dagger & 0.0 & - \\ 2 & 3 & 0.5 & 1 \times 2 \\ 3 & 6 & 1 \cdot 0 & 2 \times 3 \\ 4 & 12 & 2.0 & 3 \times 4 \\ 5 & 24 & 4.0 & 4 \times 6 \\ 6 & 48 & 8 \cdot 0 & 6 \times 8 \\ 7 & 72 & 12.0 & 6 \times 12\end{array}$

* Based on Woronecki, Ingram \& Dolbeer (1976).

$\uparrow 2 \mathrm{~cm}$ longitudinal slit made in husk at tip end but no kernels damaged. 
period when most damage to corn by red-winged blackbirds occurs (Bridgeland 1979). Each treatment was replicated four times so that a total of fifty-six maturity and damage combinations were randomly assigned to the fifty-six subplots (experimental units).

Damage was inflicted with fine-tipped forceps, simulating actual bird damage. First the husk was shredded on the upper side of the ear near the tip to expose only the necessary number of apical kernels. Then, beginning with tip kernels and proceeding in a predetermined pattern (Table 1), the kernels were damaged by pinching and removing most of the internal kernel biomass. To further simulate bird damage activity, any insects encountered were removed.

\section{Biomass accumulation determination}

At weekly intervals, starting with first damage until harvest, thirty acceptable top ears of corn were collected from randomly selected alternate subplots to determine dry matter accumulation of cobs and kernels. The ears were husked, weighed, and dried $\left(60^{\circ} \mathrm{C}\right)$ for 20 days until moisture level reached 3 to $5 \%$. The ears were then stored at room temperature (18-20 ${ }^{\circ} \mathrm{C}$ for 6 days) until ears reached an equilibrium moisture level between 5 and $9 \%$. Each sample was weighed in seven separate aliquots composed of those kernels removed from each ear at each of the six levels of damage and then all remaining kernels. Cobs were weighed and $\%$ moisture was recorded for the kernels. In addition, data were recorded on the incidence and surface area of fungus, insect and bird damage, and abnormal kernel development.

\section{Ear measurements}

Damaged, undamaged, and bottom ears from each of the fifty-six experimental units were harvested 160 days after planting, husked, and placed in burlap bags. Bottom ears were subsequently ignored in all analyses because only nine poorly developed bottom ears were present on the 3360 plants from which the top ears were taken. Bags were placed in a corn drier $\left(60-71^{\circ} \mathrm{C}\right)$ and the ears dried for 10 days and then stored at room temperature $\left(18-20^{\circ} \mathrm{C}\right)$ for 14 days until ears reached an equilibrium moisture level between 9 and $11 \%$. The damaged and undamaged samples from each unit were examined, shelled, and weighed in random order, from randomly selected plots.

Before net kernel weight was obtained for a sample, total weight, length of ear from cob butt to cob tip, and maximum kernel row length were recorded. A visual estimate was made of percentage surface area damaged and categorized as: abnormal kernel development; fungus; sprouting; insects; birds; simulated damage; and unknown. Before the undamaged sample was shelled, the kernels from the same location and pattern as were

TABLE 2. The activities associated with the design and data collection for the experiment

Activity

Cornfield planted (Pioneer 3518)

Ears silking

Kernels at blister stage

Damage at milk stage of kernel development

Kernels at dough stage

Damage at dough stage of kernel development

Corn plants at physiological maturity

Harvest of experimental units

Commercial harvest of field
Date(s)

$\begin{array}{rr}1 \text { May } & 1977 \\ 11 \text { July } & 1977 \\ 21 \text { July } & 1977 \\ 2 \text { August } & 1977 \\ 4 \text { August } & 1977 \\ 9 \text { August } & 1977 \\ 29 \text { August } & 1977 \\ 6 \text { \& } 7 \text { October } 1977 \\ 22 \text { October } & 1977\end{array}$


previously destroyed in the damaged sample were removed from all thirty ears and weighed. After shelling the thirty ears, the following data were collected: total weight; kernel weight; cob weight; and \% moisture. Net weight loss (hereafter called net loss) was computed as the difference between the kernel weight of the thirty-ear damaged sample and the thirty-ear undamaged sample for each plot. Expected loss, assuming no compensation, was obtained from the dry weight of the same number of kernels removed at the same ear locations after harvest from the undamaged thirty-ear samples. Table 2 summarizes the activities associated with the experiment.

\section{RESULTS}

\section{Dry matter accumulation}

Maximum dry matter accumulation in the cob occurred about 7 weeks and in kernels 10 weeks after silking (Fig. 1). At the time of milk- and dough-stage damage, 26 and $44 \%$, respectively, of the dry matter had accumulated in all the kernels although only 19 and $41 \%$, respectively, had accumulated in the damaged tip kernels (Table 3). Thus, from 81 to $59 \%$ of the dry matter that would have been incorporated into those kernels which were damaged was potentially still available for translocation into the remaining undamaged kernels.

\section{Visual assessment of bird damage}

In spite of attempts to minimize real bird damage, $6.5 \%$ of the ears in the undamaged sample showed bird or bird-like damage at the time of shelling. Surprisingly, $10 \%$ of the 1440 ears which had received simulated bird damage showed no sign of bird damage. Apparently low levels of damage, especially early in development, can be obscured by the growth of adjacent kernels. For example, 38 and $17 \%$ of the ears that had six kernels removed at the milk and dough stages, respectively, showed no visual evidence of damage at the time of shelling (Table 4). At harvest, the visual assessment underestimated both the incidence of damage (Table 4) and the kernel surface area damaged (Tables 3 \& 4).

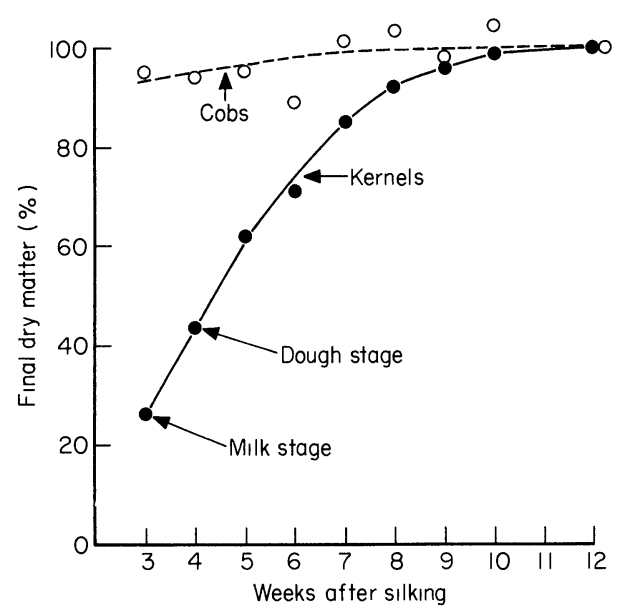

FIG. 1. Biomass accumulation in corn cobs and kernels after silking. 
TABLE 3. Percentage of the total dry matter of corn contained in the damaged kernels and the percentage of total kernel dry matter potentially available for translocation after damage

\begin{tabular}{|c|c|c|c|c|c|}
\hline \multirow{2}{*}{$\begin{array}{c}\text { No. of } \\
\text { kernels } \\
\text { damaged } \\
0\end{array}$} & \multirow[t]{2}{*}{$\begin{array}{c}\% \text { of total dry } \\
\text { matter at maturity } \\
\text { represented by } \\
\text { damaged kernels } \\
0.00\end{array}$} & \multicolumn{2}{|c|}{$\begin{array}{c}\% \text { of final dry } \\
\text { matter accumulated } \\
\text { in damaged kernels } \\
\text { at time of damage } \\
\text { milk dough }\end{array}$} & \multicolumn{2}{|c|}{$\begin{array}{l}\% \text { of total kerne } \\
\text { dry matter } \\
\text { potentially } \\
\text { available for } \\
\text { translocation } \\
\text { milk dough }\end{array}$} \\
\hline & & - & - & - & - \\
\hline 3 & 0.42 & $16 \cdot 56$ & 40.09 & 0.35 & 0.25 \\
\hline 6 & 0.86 & $18 \cdot 17$ & 39.95 & 0.70 & 0.52 \\
\hline 12 & 1.80 & $18 \cdot 76$ & $40 \cdot 48$ & 1.46 & 1.07 \\
\hline 24 & 3.79 & $19 \cdot 13$ & 39.68 & 3.06 & $2 \cdot 29$ \\
\hline 48 & 7.79 & $20 \cdot 15$ & $40 \cdot 88$ & $6 \cdot 22$ & 4.61 \\
\hline 72 & 12.05 & $21 \cdot 78$ & $42 \cdot 20$ & $9 \cdot 42$ & 6.96 \\
\hline \multicolumn{6}{|l|}{ Mean } \\
\hline 23.6 & 3.82 & 19.09 & $40 \cdot 55$ & 3.54 & 2.62 \\
\hline
\end{tabular}

TABLE 4. Visual assessment of $\%$ surface area of kernels damaged and $\%$ of ears showing bird-like damage by maturity level (undamaged samples in parentheses), 1977

$\begin{array}{ccccr}\begin{array}{c}\text { No. of } \\ \text { kernels } \\ \text { damaged }\end{array} & \begin{array}{c}\text { Mor kernel } \\ \text { surface area } \\ \text { damaged }\end{array} & \begin{array}{c}\% \text { of ears } \\ \text { showing } \\ \text { damage }\end{array} & \begin{array}{c}\text { Dough stage } \\ \text { sorface area } \\ \text { sumage }\end{array} & \begin{array}{c}\% \text { of ears } \\ \text { showing } \\ \text { damage }\end{array} \\ 0 & 0.15 & 20(8) & 0.02 & 3(2) \\ 3 & 0.32 & 49(11) & 0.38 & 73(5) \\ 6 & 0.55 & 62(14) & 0.58 & 83(2) \\ 12 & 1.27 & 94(11) & 1.40 & 96(3) \\ 24 & 2.25 & 99(6) & 2.61 & 100(3) \\ 48 & 6.24 & 100(7) & 7.74 & 100(3) \\ 72 & 9.59 & 100(13) & 11.07 & 100(3) \\ \text { Mean } & & & & \\ 23.6 & 2.91 & 75(10) & 3.40 & 79(3)\end{array}$

Net loss

Net losses are shown for each damage and maturity level in Fig. 2. In only eleven of the fifty-six plots did the thirty damaged ears weigh more than undamaged ears. Expected losses are shown in Table 3. Analysis of variance of the difference between net loss and expected loss showed no significant effects for damage level $(F=0.336)$ or time of damage $(F=0.044)$.

This analysis indicated no significant compensation in kernel weight per plot following bird damage. Two confounding problems in the experimental design and the analysis became apparent during examination of the data; therefore, the conclusion of no compensation, based on the above analysis, remained tentative. First, the amount of secondary damage (fungus, sprouting, and insect loss) was influenced by the damage treatment. Second, the experimental design with paired thirty-ear samples of damaged and undamaged ears from each plot did not reduce sampling variation enough to allow sensitive statistical tests for low levels of compensation. The variation in the average kernel weight of each sample was largely due to the between ear variation in the thirty ears comprising the sample, therefore a more accurate method for predicting the weight of the damaged 


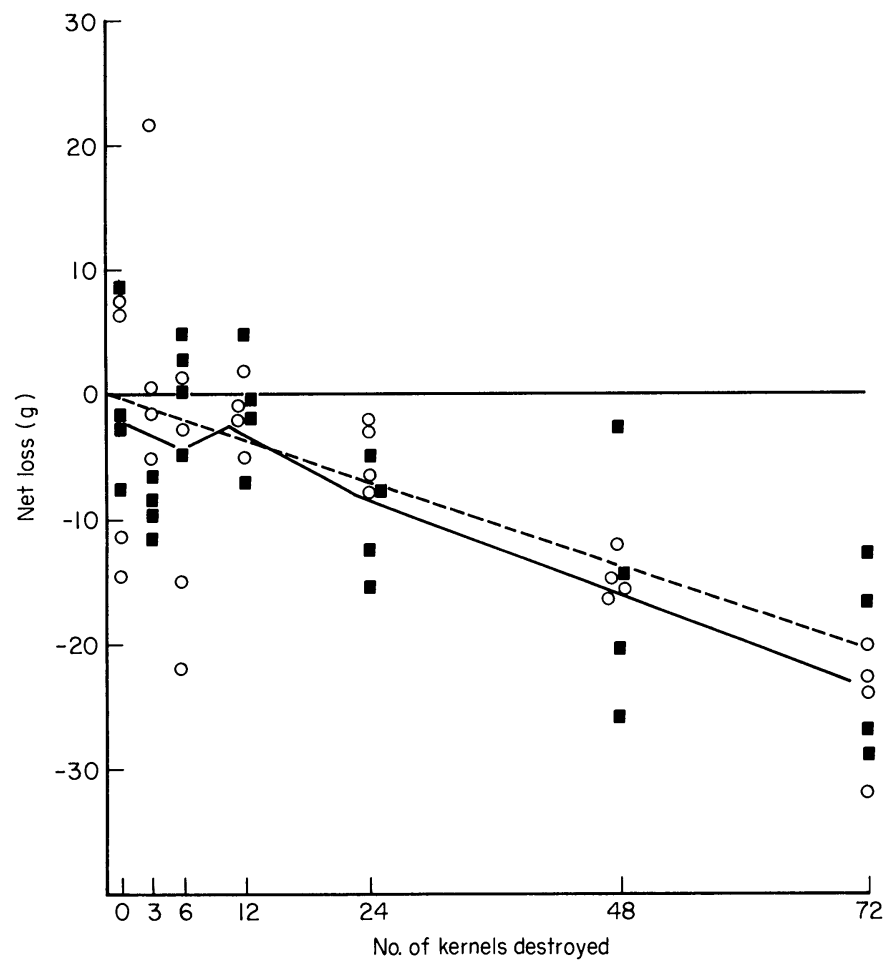

FIG. 2. Net loss of corn per ear (weight of thirty damaged ears minus thirty undamaged ears) for individual plots at each damage level. The circles represent milk-stage damage and the squares dough-state damage. The solid line is the average net loss for the eight plots at each damage level and the broken line is the expected loss based on the weight of kernels removed at harvest from the undamaged sample.

sample was needed. These two factors are now considered and then followed by a reanalysis for any compensatory response.

\section{Incidence of secondary damage}

The incidence of secondary damage differed between control and damaged ears at different damage and maturity levels (Table 5). Simulated bird damage increased the frequency of fungal infection, especially when damage was inflicted at the milk stage. Sprouting of kernels was increased only in ears having high simulated damage, twentyfour or more kernels removed, and was greatest for milk stage damage. The frequency of insect damage increased following simulated bird damage inflicted at the milk stage of maturity. The frequency of abnormal kernel development did not differ among treatments.

Since secondary damage was confounded with simulated damage it is of interest to estimate the kernel weight losses due to fungi, sprouting, or insect damage. The dry kernel weight of each thirty-ear sample was adjusted upward using a visual estimation of the proportion of the total kernel surface area showing secondary loss. In the damaged samples, secondary losses averaged $0.78 \%$ and $0.32 \%$ of the total kernel surface area at milk and dough stages, respectively, which was equivalent to $34.1 \mathrm{~g}$ (range 3.7 to $95.4 \mathrm{~g}$ ) and $14.1 \mathrm{~g}$ (range 4.1 to $26.6 \mathrm{~g}$ ) for the thirty-ear samples. For the undamaged samples, secondary losses averaged $0.19 \%$ of the total kernel surface area and $8.8 \mathrm{~g}$ (range 0.7 to $18.6 \mathrm{~g}$ ) per sample. 
TABLE 5. Percentage of ears with secondary damage following artificial bird damage

\begin{tabular}{lcccc} 
& $\begin{array}{c}\text { Number of } \\
\text { kernels } \\
\text { removed }\end{array}$ & \multicolumn{2}{c}{$\begin{array}{c}\text { Damaged ears } \\
\text { Milk }\end{array}$} & $\begin{array}{c}\text { Dough } \\
\text { Undamaged } \\
\text { ears }\end{array}$ \\
Fungus & $0-12$ & $16.9^{*}$ & $6 \cdot 7^{*}$ & \\
& $24-72$ & $25 \cdot 3^{*}$ & $6.7^{*}$ & 3.0 \\
Sprouted kernels & $0-12$ & $4 \cdot 8$ & $6 \cdot 2$ & \\
& $24-72$. & $22 \cdot 8^{*}$ & $10 \cdot 8^{*}$ & $4 \cdot 2$ \\
Insect damage & $0-12$ & $15 \cdot 0^{*}$ & $10 \cdot 4$ & $10 \cdot 5$ \\
& $24-72$ & $15 \cdot 0^{*}$ & $9 \cdot 7$ & \\
Abnormal kernel & $0-12$ & $1 \cdot 7$ & $1 \cdot 9$ & $2 \cdot 2$ \\
development & $24-72$ & $1 \cdot 1$ & $1 \cdot 4$ & \\
* Significant difference in frequency from undamaged ears $(P<$ \\
0.05).
\end{tabular}

\section{Predicted weight of destroyed kernels}

Because of the large sampling error in the estimated mean of each thirty-ear sample, instead of using the paired thirty control ears in each plot to determine what the kernel weight on the damaged ears would have been without damage, we used two characteristics of the damaged ears themselves (cob weight and kernel row length) to predict this kernel weight. This approach was prompted by the reported consistent relation between rachis weight (cob minus floral bracts) and kernel weight (Mangelsdorf 1974). Multiple regression revealed that the sum of the lengths $(\mathrm{cm})$ of the longest row of kernels on each ear and the sum of the dry cob weights ( $\mathrm{g}$ ) for each thirty-ear undamaged sample predicted the undamaged adjusted kernel weight $(\mathrm{g})$ by the equation: kernel weight $=$ $-548.7+8.129 \times$ kernel row length $+2.305 \times$ cob weight $(n=56, \quad r=0.923$, $\left.s_{y \cdot x}^{2}=5999\right)$. Using this relationship, we calculated the predicted kernel weight without any damage of each sample of thirty damaged ears, based on the kernel row lengths and cob weights of the damaged ears. Increasing damage levels did not change the maximum kernel row length $(r=0.054$, slope $=0.026, P \simeq 0.34)$ or the cob weight $(r=0.130$, slope $=0 \cdot 144, P \simeq 0 \cdot 17$ ). The $95 \%$ confidence interval for a predicted kernel weight for a thirty-ear sample was \pm 156.9 at the mean weight of $4630.1 \mathrm{~g}$, or expressed as a percentage, $\pm 3 \cdot 39 \%$.

\section{Net loss based on predicted kernel weight}

Net loss in yield due to damage can now be recalculated as the difference between the regression predicted kernel weight of each thirty-ear sample and the observed kernel weight adjusted for secondary damage. Figure 3 shows the results for each damage and maturity level. The expected loss with no compensation is based on a regression equation kernel weight $=-6.85+7.58 \times$ kernels removed, relating the weight of the same number of kernels removed at harvest from the undamaged sample with the number of kernels damaged $\left(n=56, r=0.999, s_{y}^{2} \cdot x=102 \cdot 7\right)$. Compared with Fig. 2 , the scatter between plots was reduced indicating that the thirty-ear kernel weights predicted by regression were less variable than those based on paired control ear samples. The variance estimates, unexplained variation after linear regression with damage (residual mean square $=s_{y \cdot x}^{2}$ ), were significantly different for Figs 2 and $3(F=53.09 / 6.85=7.76$ with 54,54 d.f., $P<0.001)$.

Analysis of variance indicated that the difference between net loss (predicted weight minus actual weight) and expected loss was somewhat influenced by maturity $(F=2.417$, 


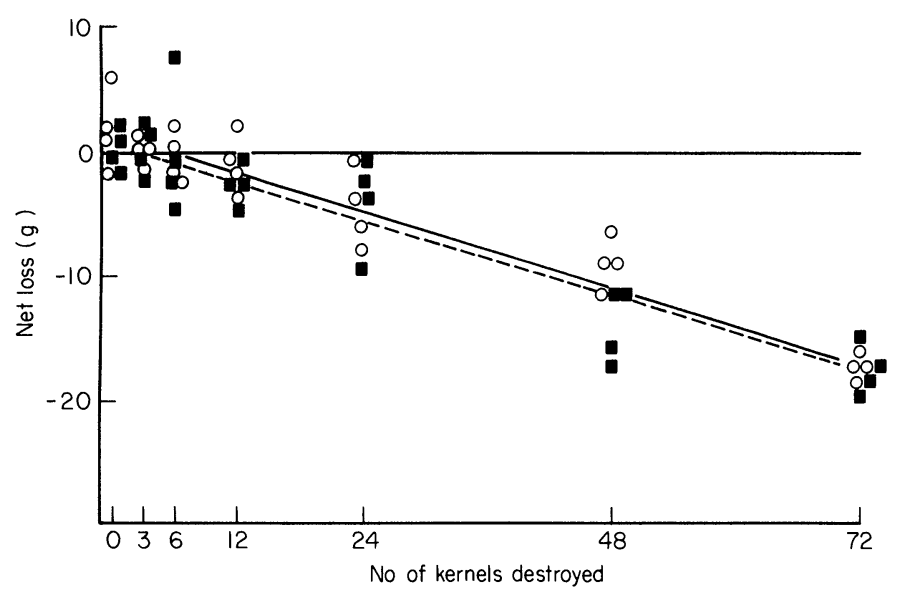

Fig. 3. Predicted net loss of corn per ear (difference between the regression predicted kernel weight of each thirty-ear sample and the actual kernel weight adjusted for secondary damage) for all damaged plots at each damage level. The circles represent milkstage damage and the squares dough-stage damage. The solid line is the predicted average net loss for the eight plots at each damage level and the broken line is the expected loss based on a regression equation relating the weight of kernels removed at harvest from the undamaged sample with the number of kernels damaged.

$P \simeq 0.124)$ but not by damage level $(F=0.250)$. For milk stage of maturity, the difference between net loss and expected loss was $39.3 \mathrm{~g}$ (1.31 g per ear), significantly greater than zero $\left(t=3.196, s_{d}=12.307, P<0.005\right.$, d.f. $\left.=27\right)$. No increased compensation occurred with increasing damage. Because the net loss and expected loss were both based on predictive equations, the variance from individual predictions should be added to variance based on the twenty-eight differences observed. When this was done, the mean difference of $+39.3 \mathrm{~g}$ was just significant $\left(t=2.047, s_{d}=19.219, P \simeq 0.052\right.$, d.f. $\left.=25\right)$. Therefore, slight partial compensation of dry weight did occur following simulated bird damage at the milk stage of maturity. An average of $39.3 \mathrm{~g}$ was recovered of the $171.9 \mathrm{~g}$ average kernel weight destroyed, or $22.9 \%$. This partial compensation amounts to $28.3 \%$ of the amount available at milk stage for translocation. At the dough stage of maturity, the average compensation of $5.6 \mathrm{~g}(3.3 \%)$ was not significant.

\section{DISCUSSION}

We conclude that slight compensation of kernel weight that partially reduced net loss occurred following simulated bird damage to tip kernels. This compensation was probably accomplished through translocation into undamaged kernels of a portion of the biomass that would have been deposited in the damaged kernels; stimulation of a plant growth response is not necessary to account for the amount of weight regained. Compensation occurred only following damage in the milk stage, 22 days after silking. The average amount of compensation was calculated to be $23 \%$ of the average potential weight of the destroyed kernels. This was equivalent to $0.86 \%$ of the total kernel weight of damaged ears, a rather insignificant portion.

Although we found that compensation did occur, certainly it was small. This contradicts the earlier reports of Dyer $(1975 ; 1976)$ where increased yield followed bird damage and is more in agreement with Duncan \& Hatfield (1964). A statement of these latter 
authors that 'kernels above and below partially developed kernels often appear to be abnormally large but later study showed that the actual weight difference was insignificant' was for the most part supported by our experiment.

Simulated bird damage, especially heavy damage early in kernel development, changed the incidence of fungus, sprouting, and insect damage that occurred before harvest. Quantification of secondary loss became necessary to separate its effect on yield from that directly due to bird damage. The magnitude of secondary loss, which in this study ranged up to $2.1 \%$ and averaged $0.78 \%$ of the kernel weight in plots damaged early in development, can certainly be as important as compensation which averaged $0.86 \%$ of the kernel weight. We now question the conclusions drawn from our analysis of the 1975 data as reported by Woronecki, Ingram \& Dolbeer (1976). Fungus incidence in 1975 was lower whereas sprout and insect damage were higher in damaged ears. Unfortunately, although the incidence of secondary damage was recorded in that study, no estimate of the extent of secondary damage was made.

An important result shown clearly in the present study was that corn kernels contain only 20 to $40 \%$ of their final biomass at the time they are usually consumed by blackbirds (Fig. 1 and Table 3). Thus, a blackbird consuming $5 \mathrm{~g}$ (dry weight) of corn per day during the milk and dough stages would actually reduce final yield of corn by 12 to $25 \mathrm{~g}$ a day plus possible additional secondary loss. This important fact has been overlooked in bioenergetics studies that use feeding rates and numbers of birds to estimate the impact of blackbird populations on corn crops (Wiens \& Dyer 1975; Williams 1975).

By way of summary, using the visual assessments of bird damage for the thirty damaged ears in each of these plots and other related data gathered in this study, we present the following example of bird damage estimation in corn. Our simulated damage field had $85.7 \%$ of the ears damaged, an average primary loss to birds of 23.6 kernels per ear. The birds would have consumed from 0.73 to $1.55 \%$ (milk and dough stage damage, respectively) of the final kernel weight which caused a loss averaging $3 \cdot 82 \%$ of the final total kernel weight (Table 3). Because some compensation through translocation of dry matter occurred, 0.86 and $0.12 \%$, respectively, damage was somewhat reduced to 2.96 and $3.70 \%$ of the total kernel weight. Visual assessment of damage at harvest estimated 75.0 and $79.0 \%$ of the ears damaged with an average kernel surface area loss of 2.91 and $3.40 \%$ for milk- and dough-stage damage, respectively (Table 4). Therefore for the distribution of bird damage and compensation observed in this study, the estimated weight loss based on visual estimation of kernel surface area damaged would underestimate actual loss only by 0.05 and $0.30 \%$ of the total kernel weight; the actual loss was 1.4 and $8.1 \%$ greater than visually estimated for early and late damage, respectively. Secondary loss, due to fungus and sprouting, increased the actual loss from $3.82 \%$ to $4.60 \%$ and $4.14 \%$ of the total dry weight for milk and dough stage damage respectively, and unless percentage surface area affected by secondary loss is also visually estimated, this would increase the difference between actual and estimated loss.

This example illustrates that primary bird damage estimates based on surface area of kernels destroyed are correlated with actual loss but the relationship can be affected by any environmental factors which influence the severity of secondary loss.

\section{ACKNOWLEDGMENTS}

We thank Gibbs Aero Sprayers, Fremont, Ohio; Schlessman Seed Co., Milan, Ohio; and Lepley Bros., Bellevue, Ohio, for cooperation and the services they provided. K. M. Cote, 
B. F. Dotson, P. C. Kleinhenz, and K. L. Marquess helped collect and tabulate the data.

D. Haugen and G. R. Rost provided field assistance.

\section{REFERENCES}

Allen, P. G. (1977). Assessment of damage to annual pastures by the pasture cockchafer, Aphodius tasmaniae Hope, in south Australia. Australian Journal of Agricultural Research, 28, 663-670.

Bridgeland, W. T. (1979). Timing bird control applications in ripening corn. Proceedings of Bird Control Seminar, Bowling Green State University, Bowling Green, Ohio, 8 (in press).

Dawson, D. G. (1970). Estimation of grain loss due to sparrows (Passer domesticus) in New Zealand. New Zealand Journal of Agricultural Research, 19, 681-688.

De Grazio, J. W., Besser, J. F., Guarino, J. L., Loveless, C. M. \& Oldemeyer, J. L. (1969). A method for appraising blackbird damage to corn. Journal of Wildlife Management, 33, 988-994.

DeHaven, R. W. (1974). Bird damage appraisal methods in some agricultural crops. Proceedings of Vertebrate Pest Conference, Davis, California, Vol. 6, pp. 246-248.

Duncan, W. G. \& Hatfield, A. L. (1964). A method for measuring the daily growth of corn kernels. Crop Science, 4, 550-551.

Dyer, M. I. (1975). The effects of red-winged blackbirds (Agelaius phoeniceus) on biomass production of corn grains (Zea mays). Journal of Applied Ecology, 12, 719-726.

Dyer, M. I. (1976). Plant-animal interactions: simulation of bird damage on corn ears. Proceedings of Bird Control Seminar, Bowling Green State University, Bowling Green, Ohio, Vol. 7, pp. 173-179.

Dyer, M. I. \& Bokhari, U. G. (1976). Plant-animal interactions: studies of the effects of grasshopper grazing on blue grama grass. Ecology, 57, 762-772.

Free, J. B. \& Williams, I. H. (1978). A survey of the damage caused to crops of oil-seed rape (Brassica napus L.) by insect pests in south-central England and their effect on seed yield. Journal of Agricultural Science, Cambridge, 90, 417-424.

Granett, P., Trout, J. R., Messersmith, D. H. \& Stockdale, T. M. (1974). Sampling corn for bird damage. Journal of Wildlife Management, 38, 903-909.

Harriss, P. (1974). A possible explanation of plant yield increases following insect damage. AgroEcosystems, 1, 219-225.

Linehan, J. T. (1967). Measuring bird damage to corn. Proceedings of Vertebrate Pest Conference, Davis, California, Vol. 3, pp. 50-56.

Mangelsdorf, P. C. (1974). Corn: Its Origin, Evolution and Improvement. Harvard University Press, Cambridge, Massachusetts.

Smith, B. D. \& Kendall, D. A. (1975). The economic significance of different levels of bird damage to plum and pear buds. Proceedings of British Insecticide and Fungicide Conference, Vol. 8, pp. 245-251.

Stern, V. M. (1973). Economic thresholds. Annual Review of Entomology, 18, 259-280.

Stone, C. P., Mott, D. F., Besser, J. F. \& De Grazio, J. W. (1972). Bird damage to corn in the United States in 1970. Wilson Bulletin, 84, 101-105.

Summers, D. D. B. \& Pollock, M. R. (1978). The effects of bullfinch damage on the yield of pear trees. Annals of Applied Biology, 329-350.

Webster, P. J. \& Walker, D. W. (1977). A field test of corn cultivars for insect and disease resistance. Journal of Agriculture of University of Puerto Rico, 61, 319-325.

Wiens, J. A. \& Dyer, M. I. (1975). Simulation modelling of red-winged blackbird impact on grain crops. Journal of Applied Ecology, 12, 63-82.

Williams, R. E. (1975). Comparative food habits among red-winged blackbirds, brown-headed cowbirds, and European starlings in relation to agricultural production in north-central Ohio. M.S. thesis, Bowling Green State University, Bowling Green, Ohio.

Wolff, J. O. (1978). Burning and browsing effects on willow growth in interior Alaska. Journal of Wildlife Management, 42, 135-140.

Woronecki, P. P., Ingram, C. R. \& Dolbeer, R. A. (1976). Response of maturing corn to simulated bird damage. Proceedings of Bird Control Seminar, Bowling Green State University, Bowling Green, Ohio, Vol. 7, pp. 163-171.

(Received 2 January 1980; revision received 10 June 1980) 